in the University of Strasbourg which he now holds. He was made an honorary fellow of the Royal College of Surgeons of England in 1937. Prof. Leriche is chiefly interested in the surgery of the stomach, bones, joints, the sympathetic system, and diseases of arteries. This is the sixth occasion of the award, which is made by a Committee representative of the Royal Society, the Royal College of Surgeons of England, the Royal College of Surgeons in Ireland, the University of Edinburgh, and the University of Glasgow.

\section{Dr. D. T. A. Townend}

DR. D. T. A. TownEND has been appointed Livesey professor of coal gas and fuel industries in the University of Leeds. After nearly four years of war service, Dr. Townend entered the East London (now the Queen Mary) College, London. He graduated in 1920 and then proceeded to the Department of Chemical Technology at the Imperial College of Science, London, for post-graduate study and research under Prof. W. A. Bone. He has since collaborated with Prof. Bone more particularly in investigating gaseous explosions at high initial pressures. Dr. Townend was awarded successively a Salters' research fellowship and a Rockefeller international research fellowship. He has been largely concerned in the equipment and organization of the High Pressure Laboratories at the Imperial College. Dr. Townend, who is a recognized teacher in the University of London, is an authority on combustion and highpressure problems and has published many books and articles both independently and in collaboration with his colleagues at South Kensington.

\section{U.S. National Academy of Sciences: New Members}

AT the annual meeting of the U.S. National Academy of Sciences held on April 25-27, the following were elected foreign members : Prof. Alfred Fowler, emeritus professor of astrophysics, Imperial College of Science and Technology, London; Prof. Pierre Janet, professor of psychology, Collège de France, Paris; Dr. S. P. L. Sorensen, director of the chemical division of the Carlsberg Laboratory, Copenhagen; and Prof. D. M. S. Watson, Jodrell professor of zoology and comparative anatomy, University College, London. The following members were also elected : Prof. M. H. Stone, professor of mathematics, Harvard University ; J. A. Fleming, Department of Terrestrial Magnetism, Carnegie Institution of Washington ; Dr. C. D. Anderson, California Institute of Technology; Prof. G. W. Stewart, professor of physics, University of Iowa; Prof. Theodor von Kármán, director of the Daniel Guggenheim Laboratory, California Institure of Technology ; Prof. W. K. Lewis, professor of chemical engineering, Massachusetts Institute of Technology ; Prof. C. S. Marvel, professor of organic chemistry, University of Illinois; Prof. W. H. Rodebush, professor of physical chemistry, University of Illinois ; Prof. W. H. Bucher, professor of geology, University of Cincinnati; Prof. L. J. Stadler, professor of field crops, University of Missouri ; Prof. T. S. Painter, professor of zoology, University of Texas ; Prof. W. de Berniere MacNider, professor of pharmacology, University of North Carolina; Prof. E. Adelberg Doisy, professor of biochemistry, St. Louis University; Prof. S. B. Wolbach, professor of pathological anatomy, Harvard University; Prof. L. L. Thurstone, professor of psychology, University of Chicago.

\section{Metal-Mining Enterprise}

Sir Warington SMxTH was the first professor of mining at the Royal School of Mines, and his forty years of service coincide with one of the most momentous changes in the history of the world, namely, the growth of industry on a metallic foundation. Prof. S. J. Truscott showed, in his Warington Smyth Memorial Lecture delivered on May 5 (Pp. $38+$ 2 plates. London: Macmillan and Co., Ltd. 1s. net)how to-day everything civilized man enjoys depends on metals; without them rapid transport, modern housing, preservation of foodstuffs, etc., are im. possible. Metals are durable as contrasted with vegetable and animal products, which are used once, whereas metals can be and are refabricated. The annual production of fresh supplies of metal merely augments the amount already in use, an amount greater in value than the total of all other commodities utilized by man. Metals, with the exception of gold, are not found to any extent as native metal and have to be extracted from highly complex ores. The enterprise of the miner has made many valuable discoveries such as the Bessemer process for ferrous metallurgy, the McArthur cyanide process for precious metallurgy and the flotation process for the base metals, and probably the same enterprise will find a cheap method of producing the light metals such as aluminium and magnesium. Further enterprise has rendered available vast sources of minerals which would otherwise have remained valueless, and in addition has shifted the centre of production of certain metals, for example, copper, from one continent to another. As the result of the exploitation of these processes combined with similar advances in engineering technique, one part of gold in 200,000 is being won at a profit, and one hundred million tons of base metal minerals are being treated by the flotation process per annum.

\section{Mining Engineering as a Profession}

IN his presidential address delivered on May 19 to the Institution of Mining and Metallurgy, Dr. C. B. Kingston discussed "Mining Engineering as a Profession". He said that mining is essentially a man's job and offers a splendid career to the keen ambitious man who is not seeking security first but likes a spice of adventure and finds satisfaction in a con. structive occupation that makes some definite contribution to the world's welfare. The training of a modern mining engineer should be based on a sound general education, as not only must he be a technician but also in addition a man of affairs, a competent negotiator and preferably a linguist. The technique of mining is difficult to define, as it is all-embracing in its requirements, but briefly it can be described as the application of all the applied sciences to finding, winning and subsequent preparation for the market of a mineral deposit. The increasing importance 
of metal in the world's affairs is creating further demands on a mining engineer's accomplishments in an ever-widening field of activity and with largerscale operations than ever before. A study of history, ancient and modern, in terms of minerals is fascinating because the growth of nations and the cause of many wars cannot be dissociated from the possession or a determination to secure control of high-grade deposits of essential minerals. The question has been asked, "Who owns the earth ?", and the answer given is "The nation which controls the greatest mineral resources."

\section{Roman Wroxeter}

RECENT excavations on the site of the Roman city of Uriconium, which lies beneath the modern Wroxeter, five miles from Shrewsbury, were described by Miss Kathleen Kenyon, the field director of the excavation, at a meeting of the Society of Antiquaries of London on May 12. Some years ago excavations were carried out with the object of determining the position and character of the defences of the legionaries' camp, but without success, nor has investigation been more successful on the present occasion. Much information, however, has been obtained about the history of the city. It would appear that Uriconium, which was the fourth largest Roman city in Britain, was founded about A.D. 48 as the headquarters of the Fourteenth and Twentieth Legions, of which it was the station while Wales was being subdued. When the legions were moved to Chester, Uriconium became the tribal capital of the Cornovii. Two successive defensive systems of the city have been found, of which the earlier, dating from about the end of the first century of our era, enclosed a much smaller area than the later. This latter dates from the middle of the second century, and encloses about 170 acres. It marks the largest expansion of the town. The structure known as the Baths Building, which was excavated in 1859 , was re-examined. It was found that originally it had not been intended for use as baths, but had consisted of two ranges of large rooms on either side of an enclosed courtyard, with a long two-sided hall beside it. This was built about A.D. 140 and must have formed part of the public buildings, possibly the law courts, of the town. The Forum opposite was nearly contemporary. Not very much later the whole was transformed into an elaborate and complicated bath of the usual Roman type. An interesting discovery was the body of an infant which had been placed below the floor at the time of the alteration, possibly as a foundation burial. At the end of the third century the building was des. troyed by fire, but was restored in a partial and slipshod manner. It remained in use for a further hundred years.

\section{Archrological Exploration in the Panjab}

Althобgh a considerable period of time has elapsed since the Government of India, soon after the discovery of Mohenjodaro and Harappa, decided to allow duly accredited archæological expeditions from outside India to explore Indian archæological sites, little advantage, unfortunately, has been taken of the opportunity. Two American expeditions and one Belgian have visited India, of which the American expedition to the Salt Hills under Dr. H. de Terra, in a series of investigations extending over several years, has produced much valuable palæontological and archæological material. The excavations at Mohenjodaro for the Archæological Survey were conducted by Dr. E. Mackay, who has since been in charge of further investigations in the Indus valley; but although Dr. Mackay may be regarded as a British excavator, no British expedition has been sent out. This neglect of opportunity is the more to be deplored in view of the evident importance of India for understanding of early cultural development in the Near and Middle East. India itself is now to make an effort to repair this neglect by the inauguration of a "Panjab Exploration Fund", on behalf of which an appeal is issued by Diwan Chaman Lall, president ; Prof. E. Dickinson, acting president ; and Dr. C. L. Fabri, field director. Funds have been collected in India to begin excavation in the coming autumn on the ancient city site of Surkanwali Ali, near Bhera on the Jhelum, where trial excavations have been made recently by the field director of the Fund. These have revealed the existence of at least five superimposed cities, dating from the Moghul period to pre-Buddhist times. The Fund has the support of the principal scholars and notabilities of the Panjab. A considerable sum is required to place the Fund on a permanent basis ; and if a sufficient amount can be raised, it is proposed also to found an ethnographical and archæological museum, for which nucleus collections are already in hand. Contributions should be addressed to the "Panjab Exploration Fund", Imperial Bank, Lahore, or to the London Branch of the Bank, 25 Old Broad Street, London, E.C.2.

\section{Prehistoric Mines in East Africa}

Exploration of a cave in the Njoro Forest Reserve of Kenya by Dr. L. S. B. and Mrs. Leakey has brought to light cultural evidence, which they believe, it is stated by the Nairobi correspondent of The Times (May 23), points to a connexion with prehistoric opal mining on an extensive scale. The excavations have shown that this cave was used as a place for the disposal of the dead of stone age man. The bodies were brought to the cave, placed in a shallow excavation, and burnt to ashes by a fire lit over them. As time went on, the earlier ashes were disturbed by later incinerations, and the remains of at least sixty bodies have been discovered. The large number of cultural objects found include five hundred stone and one thousand bone beads. The stone beads are especially interesting, as among them are specimens of what appear to be jade and opal, as well as rock crystal and green quartz. Attractive jade pendants were also found. Many of the beads are said to show skilful workmanship, and it is therefore suggested that they may have been brought to East Africa by traders from Egypt and Mesopotamia. The beads are being submitted to experts in England for examination and report. It has been possible to reconstruct from charred fragments both basket work and rope work, and an exquisitely carved wooden vessel. Dr. Leakey, it is stated, 